\title{
Wartime Illusions and Disillusionment: \\ Camp Dodge and Racial Stereotyping, 1917-1918
}

\section{BILl DOUGLAS}

ON THE FOURTH OF JULY, 1918, celebrants at Des Moines's Hyperion Golf Club had their festivities interrupted by the sounds of construction of a scaffold across the property line at the south end of Camp Dodge. Children asked their mothers what was going on. "All knew, but none would say," the Des Moines Evening Tribune ominously reported. Construction lasted all night in the pouring rain. The next morning was sunny, hot, and humid, and a much different crowd gathered at the club. Hundreds of civilians, who had been banned from the base for the morning, craned and pointed opera glasses at a much larger gathering inside the camp. There, the forty thousand white troops of the 88th Division and the three thousand African-American troops of the 92nd witnessed the hanging of three African-American conscripts from Alabama-Robert Johnson of Tuscumbia, Fred Allen of Georgianna, and Stanley Tramble of Roanoke or Stroud-for the rape of a white woman. Attendance was compulsory.

1. Des Moines Evening Tribune, 5 July 1918; Des Moines Capital, 6 July 1918; Camp Dodger, 5 July 1918; Des Moines Register, 5 July 1978. The Register article said Allen was from Mississippi; the Camp Dodger said all were from "southern states." The Capital and the Tribune both listed the Alabama towns. Since Tuscumbia is in northwesternmost Alabama, near the Mississippi line, both state affiliations could be correct.

THE ANNALS OF IOWA 57 (Spring 1998). CThe State Historical Society of Iowa, 1998. 
This event, which dominates the recorded memories of those who were at Camp Dodge in July 1918, was reported in detail in Des Moines's mainstream white press (but ignored by the state's most prominent African-American newspaper, the Bystander). The reports in the press and descriptions by other white observers broke through some of the stereotypes that had characterized earlier reporting about African Americans at Camp Dodge. ${ }^{2}$

In other ways, however, the event was a tragic culmination of an experiment in race relations that had begun with high hopes. The vast majority of African-American leaders, most notably W. E. B. Du Bois, had made a calculated decision to support World War I as a quid pro quo for possible racial advancement. If African-American troops trained and fought alongside white troops, they reasoned, there would be cause to hope that African Americans could be integrated into American society after the war. The advances, however, depended to a significant degree on changing the attitudes of the majority white populace, and by and large, those attitudes remained unchanged. Thus the gains turned out to be disproportionately small in comparison to the sacrifices, and African Americans' particular disillusionment after the war exceeded the general cynicism induced by the war.

2. See interviews with Pete Bolt, Ura Hostetler, A. D. Wenger, Herman B. Neufeld, Frank J. Neufeld, J. E. Hiebert, John D. Heppner, Jesse Schwartzendruber and John Detweiler, all in Schowalter Oral History Collection, Bethel College, North Newton, KS; Torin R. T. Finney, Unsung Hero of the Great War: The Life and Witness of Ben Salmon (Mahweh, NJ, 1989), 46; and Mennonite Central Committee, Sourcebook: Oral History Interviews with World War One Conscientious Objectors (n.p., 1986), 174. A good introduction to Camp Dodge during World War I can be found in Timothy Grover, "Camp Dodge," Iowan 36 (1987). Two unpublished papers provide different perspectives on the events treated here: Matt Caswell, "Camp Dodge and the Training of African Americans during WWI" (undergraduate paper, Des Moines Area Community College, 1995, copy in author's possession), is based almost entirely on the military organ, the Camp Dodger; Derryn Moten, "A Dishonorable Death: The Semiotics of a 'Legal Lynching'" (unpublished paper, University of Iowa, 1994, photocopy at State Historical Society of Iowa, Iowa City), is especially valuable for navigating the intersections of race and gender that frame the hangings.

3. See Stuart I. Rochester, American Liberal Disillusionment in the Wake of World War I (University Park, PA, 1977). For a debate on Du Bois's motives, see William Jordan, "'The Damnable Dilemma': African-American Accommo- 
Some of the origins of the disillusionment can be seen in the way African Americans were received when they arrived at northern training camps, such as the one at Camp Dodge. ${ }^{4}$ The local press, reflecting attitudes held more broadly in Des Moines, received the black recruits warmly. Editorials and news reports reflected a pride that African Americans, many of whom had been recruited from the South, were treated much better in the North than they had been the South. Yet signs of paternalism and misunderstanding are evident in retrospect. The black recruits were expected to be cheerful, ignorant, loyal, and grateful to be in the North. The prevalence of such stereotypes overwhelmed any evidence of African Americans' dissatisfaction with or opposition to existing race relations. As long as the implications of those stereotypes remained unacknowledged, the white residents of Des Moines were able to maintain the illusion that everyone was content with the existing state of race relations. That illusion left little motivation for white people to support enhanced opportunities for African Americans or to improve relations between the races. Just as the stereotypes in the press obscured the nature of race relations in the community, segregation limited interracial encounters within the camp. Only the extraordinary horror of sharing the forced witnessing of a triple hanging created-at least temporarily-a bond of common humanity.

ACCORDING TO THE 1915 STATE CENSUS, 4,475 African Americans resided in Des Moines, a little over a quarter of the total black population of the state. As in most other localities, African Americans had experienced setbacks in the early

dation and Protest during World War I," and Mark Ellis, "W. E. B. Du Bois and the Formation of Black Opinion in World War I: A Commentary on 'The Damnable Dilemma,'" both in Journal of American History 81 (1995), 1562-90.

4. Although scholars have largely ignored African-Americans' experience in training camps, they have studied in detail African-Americans' participation in the European theater of the war. See, for example, Arthur E. Barbeau and Florette Henri, The Unknown Soldiers: African-American Troops in World War I (1974; reprint ed., New York, 1996); Gerald W. Patton, War and Race (Westport, CT, 1981); and Emmett J. Scott, Scott's Official History of the American Negro in the World War (Chicago, 1919). 
twentieth century in Des Moines. Work in unionized construction trades had closed to them, most notoriously when the bricklayers union instigated a strike of African-American workers and then brought in strikebreakers to replace them. Segregation in housing became systematized by the use of covenants; and, according to one contemporary African-American scholar and observer, discrimination was practiced everywhere, especially in theaters, restaurants, and hotels. ${ }^{5}$

At the same time, Iowa had established a reputation as a state advanced in race relations. That reputation had originated with the passage of the 1880 referendum that repealed the white-only language in the state constitution. Des Moines's reputation was enhanced when it established a thriving NAACP chapter in $1915 .{ }^{6}$ Largely on the strength of its reputation for progressive race relations, Des Moines was chosen as the site of the nation's first and only training camp for AfricanAmerican officers during World War I. The opening of Fort Des Moines in June 1917 signaled an auspicious beginning for the new era of race relations in Iowa's capital city-especially when the army insisted that no segregation would be tolerated among any establishments doing business with the army or its soldiers. The story of Fort Des Moines, on the city's south side, thus became an important part of the history of African-American progress. It is a well-told story that has overshadowed that of the lesser-known training camp for conscripts, Camp Dodge, just northwest of the city.

5. G. Victor Cools, "The Negro in Typical Communities in Iowa" (M.A. thesis, State University of Iowa, 1918), 7, 23-24, 59. No adequate history of race relations in Iowa exists for the period, but useful comparisons may be made to a study of neighboring Illinois; see Donald F. Tingley, The Structuring of a State: The History of Illinois, 1899-1928 (Urbana, IL, 1980), chap. 10. See also Leola Nelson Bergmann's ground-breaking but dated The Negro in Iowa (Iowa City, 1969).

6. Robert R. Dykstra, Bright Radical Star: Black Freedom and White Supremacy on the Hawkeye Frontier (Cambridge, MA, 1993), especially chap. 12; Jack Lufkin, "The Founding and Early Years of the National Association for the Advancement of Colored People in Des Moines, 1915-1930," Annals of Iowa 45 (1980), 439-61.

7. Barbeau and Henri, The Unknown Soldiers, 63; Patton, War and Race, chap.

3; Hal S. Chase, "Struggle for Equality: Fort Des Moines Training Camp for Colored Officers, 1917," Phylon 39 (1979), 297-310; Davenport Democrat, 24 June 1917; Bystander, 20 July 1917. After the officer training camp at Fort Des 
If the history of Fort Des Moines represents the story of what W. E. B. Du Bois called the "Talented Tenth" of African Americans who volunteered to serve as officers in the World War I army, the history of Camp Dodge extends the story to the thousands of African Americans who were drafted into military service. The rapid adoption of conscription reflected the need for hundreds of thousands of troops if the United States were to tip the scales in favor of the Allies in the impasse of trench warfare in Europe. Over the objections of southern congressmen, black men as well as white were required to register on June 5, 1917. ${ }^{8}$ Because of the objections, separate drafts for African Americans and whites would ensure segregated army units at the sixteen rapidly constructed national army training camps for conscripts. Construction workers strained over the summer to complete the sixteen new "soldier cities" designed to hold more than forty thousand conscripts apiece- "A Notable Achievement in the History of Building," gushed the National Geographic. Among the sixteen camps was Camp Dodge, designed originally to induct and train draftees from Iowa, Minnesota, North Dakota, and the central third of Illinois. Claiming "3,000 more hours of sunshine" than any other potential site, Des Moines successfully lobbied to get Camp Dodge built on its National Guard base. "Dryness," however, was probably a more important factor than "sunniness"; the War Department worried that recruits would have easy access to liquor at the competing site, Fort Snelling, Minnesota, within St. Paul's city limits.

Moines closed, a few black officers were trained as replacement officers at six of the National Army bases, including Camp Dodge. Barbeau and Henry, Unknown Soldiers, 57; Bystander, 3 May 1918.

8. With more loyalty than accuracy, the African-American St. Paul Appeal, 9 June 1917, claimed that "not a single colored citizen was delinquent in any way whatsoever" on registration day. St. Paul was a hub of public nonregistration activity for (white) radicals; see Bill Douglas, "The Germans Would Court-Martial Me, Too': St. Paul's World War I Socialist Draft Resisters," Minnesota History 55 (1997), 286-301.

9. 88th Division in the World War of 1914-1918 (New York, 1919), 15; William Joseph Showalter, "America's New Soldier Cities," Natonal Geographic 32 (1917), 439, 441, 461-62; Franklin F. Holbrook and Livia Appel, Minnesota in the War with Germany, 2 vols. (St. Paul, 1928-32), 1:309. On the Wilson administration's campaign against access to liquor in the military, see Weldon B. 
Although African-American newspapers widely reported Secretary of War Newton Baker's statement that black conscripts would train at the bases nearest them, the War Department was reluctant to train southern blacks along with southern whites at the same training camps. ${ }^{10}$ As a result, many more African Americans from outside the region came to Iowa to train as conscripts at Camp Dodge than as officers at Fort Des Moines. Probably ten to fifteen thousand African Americans took basic training at Camp Dodge during World War I, the majority of them from Alabama. ${ }^{11}$ Northern blacks, primarily from Camp Dodge's original pool of draftees from Iowa, Minnesota, North Dakota, and central Illinois, were also sent to Camp Dodge in a separate, segregated draft, but their numbers did not approach those of their southern comrades. ${ }^{12}$ Despite the army's professed intolerance of segregation in the community's business establishments, segregation was the rule within the camp; African-American companies were quartered

Durham, "'Big Brother' and the 'Seven Sisters': Camp Life Reforms in World War I," Military Affairs 42 (1978), 57-60. Cedar Rapids also wanted the base. Des Moines News, 24 June 1918.

10. St. Paul Appeal, 15 and 29 September and 10 November 1917; Bystander, 15 September 1917.

11. Des Moines newspapers reported three thousand Alabama African Americans in camp in July 1918. Since at least three rotations of troops were trained and shipped out in the fourteen months between September 1917 and the Armistice, and since smaller numbers of blacks from the Midwest were also sent to Camp Dodge in the segregated draft, ten thousand seems a conservative estimate. Compare Federal Writers' Project, "The Negro in Iowa," manuscript, box 1, State Historical Society of Iowa, Des Moines, which puts the number at 15,000. In November 1917 the Bystander put the AfricanAmerican count at 7,000, "more than the total population of colored people in Des Moines and Buxton combined." This number included 327 from the north. Bystander, 19 October and 2 and 23 November 1917. Another local paper, the Des Moines Capital, 18 October 1917, put the count for Iowa African Americans in the first call, scheduled to arrive 27 October 1917, at 127.

12. Louis G. Lasher, Report of Iowa Adjutant General, 1917-1918 (Des Moines, 1919), 587, says 880 colored Iowans were inducted; Bergmann, The Negro in Iowa, 58, cites 929. Compare Federal Writers' Project, "The Negro in Iowa," typewritten pp. 401-2/handwritten pp. 322-23. The War Roster Commission of the State of Iowa reported 993; manuscript commission report, file folder 7k, Iowa Gold Star Museum, Camp Dodge. The trouble with all those numbers is that perhaps not all Iowa African-American conscripts were sent to Camp Dodge; certainly not all Iowa whites were. 
at the southernmost edge of Camp Dodge..$^{13}$ Those units would eventually be assigned, along with African Americans from other camps, to the 92nd Division and then the 366th Infantry, which would not be fully assembled until the troops were in France.

LOCAL NEWSPAPER COVERAGE of the arrival in Des Moines of African Americans from Alabama provides ample and often painful evidence of northern editors' paternalism and blatant stereotyping, which underlay a pervasive racism. Most numerous are the allegedly humorous dialect stories. One example among the many that could be cited is the headline in the Des Moines Capital: "Pie-Eating 'Cullud' Lad At Soldier City Sho-Nuff In Love With Birmingham, Agnes and Camp. ${ }^{\prime 14}$ More insidious was a report that sounded substantial but turned out to be based on hearsay. A headline in the Capital alleged, "Many Dodge Negroes Don't Know Who the Kaiser Is Or What They Are Going To Europe To Fight For." The reporter's source for this story was not interviews with black recruits but the director of the camp's Young Men's Christian Association. Additional reason for skepticism about the story comes from contemporary and subsequent scholarly commentary suggesting that the " $Y$ " was perhaps the most racist and segregated of the volunteer organizations serving U.S. soldiers' social needs. ${ }^{15}$

Such stereotyping was not restricted to portrayals of African Americans; Chinese, Native Americans, Mexican Americans, Jews, and Arab Americans would all be conscripted, and each

13. "Historical Utilities Report," February 1919, Iowa Gold Star Museum, Camp Dodge.

14. Des Moines Capital, 7 March 1918. For other examples, see ibid., 31 October and 2 and 15 November 1917; Des Moines Register, 19 August 1917 (cartoon), 28 October, and 7 December 1917; Dorothy Ashby Pownall, "A Girl Reporter at Camp Dodge," Palimpsest 47 (1966), 237; and Camp Dodger, 7 December 1917.

15. Des Moines Capital, 15 November 1917; Barbeau and Henri, Unknown Soldiers, 40-41; Nina Mjagkij, Light in the Darkness: African Americans and the YMCA, 1852-1946 (Lexington, KY, 1994), 67-68. The African-American weekly the St. Paul Appeal, 6 July 1918, referred to the YMCA as "that travesty of Christianity." 


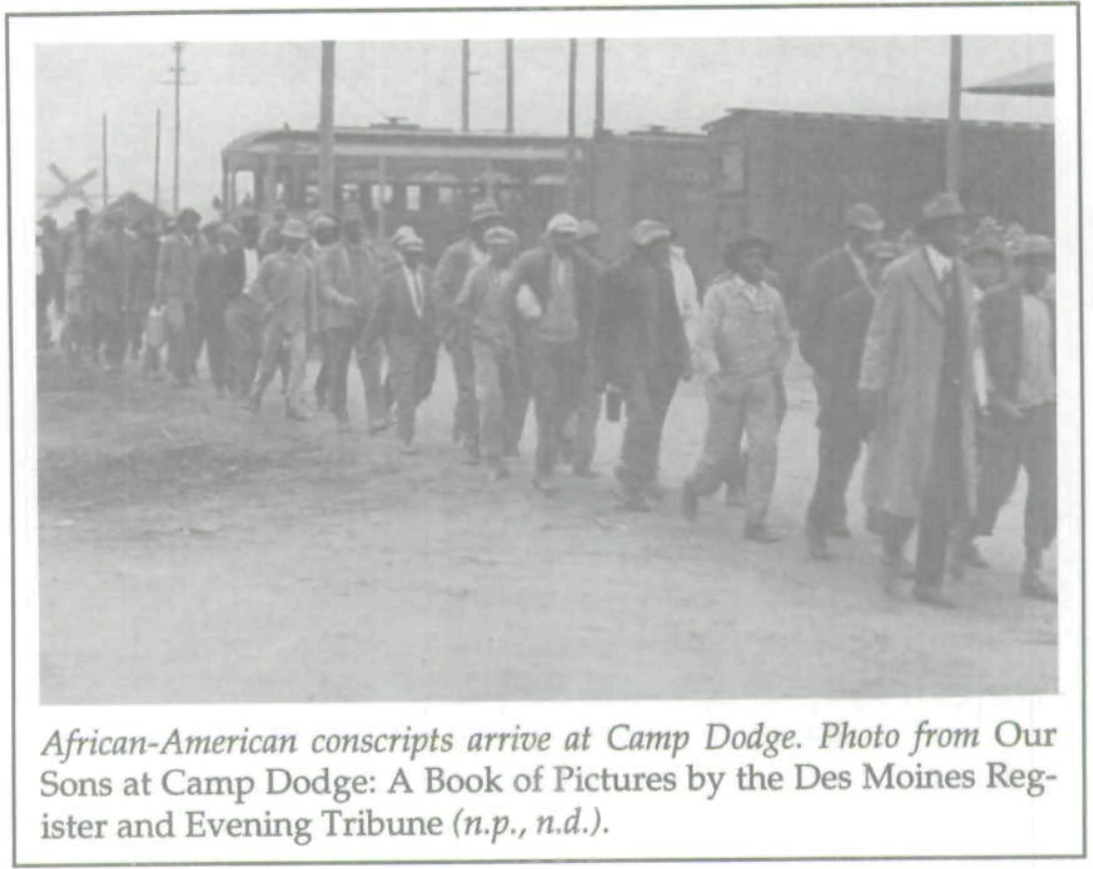

group would face its distinctive stereotype in reporting. The St. Paul Pioneer Press reported of that city's first Chinese draftee that "Lum Foo Likee Glo To Fightee As U S Draftee"; he was quoted as saying, "me likee glo Camp Dodge; me makee good sojier." One local paper seemed astonished—and a little disappointed-that Native Americans from North Dakota "came dressed like other men"; it also took the opportunity to compare the "young braves' . . . cruelty" with that of the Germans, who were reportedly "more refined and deadly than the uncivilized Indians. ${ }^{\prime 16}$

16. Ottumwa Courier, 18 February 1918; Des Moines Evening Tribune, 16 August 1918, 12 November 1917; St. Paul Pioneer Press, 10 February 1918; Des Moines Capital, 7 May and 12 July 1918 and 27 September 1917. Mexicans who worked in Iowa but did not speak English had a particularly hard time finding out about the draft registration requirement (which included aliens). Davenport Democrat, 27 and 28 June 1917; Ottumwa Courier, 25 September 1917. Mason City authorities enlisted the aid of an Immigration Department official, "who speaks Mexican fluently" in getting Mexican nationals to register late, but one remained defiant and in jail. Mason City Weekly GlobeGazette, 7 June 1917. 
Local papers made much of the contrast between conditions in Iowa and the bigotry and discrimination African Americans faced in the South. For African Americans who came to Iowa from the South, the change did, in fact, promise a less racist environment and a better opportunity to confront racism when it occurred. The Des Moines Evening Tribune, probably the most sympathetic of the major Des Moines dailies to the plight of African Americans, ran a horror story about a black Alabama soldier named Richard in the base hospital who was glad of the war and his conscription because it got him out of peonage. His boss had him put in jail whenever he had tried to quit. ${ }^{17}$ The Evening Tribune reported another southern African American as saying of his assignment to Camp Dodge during World War I, "Say man, I nevah was in de United States befoh I came to Ioway. ${ }^{\prime \prime 18}$ While the reporter probably intended the statement to be an example of what passed for dialect humor, the assertion did reflect a new reality for the African-American soldier.

Iowa newspapers also reported huffily about the inferior job southern draft boards did in providing exemptions for African Americans, noting that clergy, men with dependents, and men over age 31 were being drafted; moreover, camp doctors had to reject about 20 percent of the African-American conscripts because of physical disabilities that should have exempted them from the draft in the first place. One hapless recruit even claimed to a reporter, "I wasn't even drafted. I was on the back platform of the train, saying good bye to my buddy, when this officer busted up and said, 'I'm one man short-come on!'

17. Des Moines Register, 8 December 1917; Des Moines Evening Tribune, 6 August 1918. Sometimes even conscription was insufficient to relax an employer's hold; an Alabama-based Bureau of Investigation agent found that a fraudulent claim of mental incompetence in a Selective Service case was the result of a boss not wanting to lose a "good negro" worker, even though the draftee was eager to report. Apparently induction of the prized employee was sufficient punishment for this obstruction of the draft. F. D. Jones report, Birmingham, AL, 4 August 1918, National Archives, Record Group 65, \#252938, in Theodore Kornweibel, ed., Federal Surveillance of Afro-Americans (1917-1925): The First World War, The Red Scare, and the Gravey [sic] Movement (Frederick, MD, 1985), reel 11, 0060.

18. Des Moines Evening Tribune, 10 November 1917. 
And here I am. ${ }^{19}$ The emphasis on the improved conditions for African-American recruits in the North was to some extent justified, but the contents of the reports as well as the stereotypes they contained also sustained an illusion for readers that obscured the actual state of race relations in the North.

\section{AFTER THE ARRIVAL STORIES, Des Moines faced its first test as a host for what the Davenport Democrat was calling "The Continuing Exodus." The movement of conscripts north was part of a larger migration of southern African Americans to the North. That migration was intensified by the labor short- age and the consequent boost in wages due to World War I, but it was well under way before the U.S. entry into the war. ${ }^{20}$ What if, the Des Moines Chamber of Commerce worried, other Alabama African Americans followed the soldiers north? Prominent Des Moines leaders, joined by several local black allies who were concerned about the decline in morals "camp followers" would bring to the community, called for action to prevent such migration. ${ }^{21}$}

19. Des Moines Register, 1 November 1917; Camp Dodger, 18 January 1918; Rev. Arthur Wilson court-martial transcript, National Archives, RG 153, \#1221180; Record of Trial by General Court Martial of Private Stanley Tramble, May 31, 1918, Camp Dodge, Iowa, photocopy at State Historical Society of Iowa, Iowa City (original transcript at National Archives); Des Moines Evening Tribune, 17 January 1918; Pownall, "Girl Reporter," 237.

20. The Davenport Democrat, apparently in a bipartisan mood, reprinted on 24 June 1917 an editorial from the Springfield Republican titled "The Continuing Negro Exodus." Citing W. E. B. Du Bois on the contrasting conditions in the North and the South, the editorial recognized the demographic phenomenon of black flight northward, a wave increased significantly by high wartime wages. Two useful looks at how southern black migration affected northern cities are Peter Gottlieb, Making Their Own Way: Southern Blacks' Migration to Pittsburgh, 1916-1930 (Urbana, IL, 1987); and Joe William Trotter Jr., Black Milwaukee: The Making of an Industrial Proletariat (Urbana, IL, 1985). See also Emmett J. Scott, Negro Migration during the War (New York, 1920), 26, 89; and Carole Marks, Farewell-We're Good and Gone: The Great Black Migration (Bloomington, IN, 1989), chap. 2. The agricultural crisis created by the spread of the boll weevil also contributed to the migration, but Marks argues that rural African Americans were pushed off the farms and into southern cities, lowering wages and encouraging skilled urban workers to go north.

21. Bystander, 16 November and 7 December 1917; Des Moines Capital, 1 and 10 November and 3 December 1917; Des Moines Register, 26 November 1917. 
While the African-American population of Polk County increased substantially during the second decade of the century, much of the increase took place for the U.S. entry into the war and can be attributed to high wartime wages, the southern agricultural crisis, and Iowa's coal boom. The Camp Dodger credited letters home from Camp Dodge as aiding the migration northward, but did not suggest that migratory workers headed for Iowa. (The letters' reports of a mild winter turned out to be premature, as readers of the camp paper would have known by the time the item appeared; 1918 was Iowa's coldest winter in a generation). ${ }^{22}$ Certainly a private would have had difficulty stretching his salary, even if it exceeded what most African Americans were earning in Alabama, to provide transportation north and housing once there for his family. ${ }^{23}$ Nonetheless, the improbability of a major influx of civilian African Americans did not prevent a hue and cry against the supposed invasion. Governor William Harding of Iowa actu-

22. Camp Dodger, 11 January 1918; U.S. Department of Agriculture, Climatological Data: Iowa Section, February 1918, 15, 19, 20. Polk County's "colored" population increased from 3,616 in 1910 to 4,488 in 1915 and 5,837 in 1920; statewide, the "colored" population rose in the same years from 15,580 to 16,744 to 19,005 . Census of Iowa for 1925, 718-23. Cools, "The Negro in Typical Communities," 7, suggests that any influx due to Camp Dodge was temporary. Marcus L. Hansen, Welfare Work in Iowa (Iowa City, 1921), 24; Bergmann, The Negro in Iowa, 60; and James L. Hill, "Migration of Blacks to Iowa, 1820-1960," Journal of Negro History 66 (1981-82), 299, all take the presence of African Americans at Camp Dodge and the increase in AfricanAmerican population as cause and effect. But the motives of those fearful of an influx of blacks need to be taken into account. Some middle-class African Americans feared a disruption of the status quo by lower-class, less educated southern African Americans. And many whites used Camp Dodge as a scapegoat for general uneasiness about the overall migration northward. For an account of similar unease that exaggerated black population increases, see Elliott M. Rudwick, Race Riot at East St. Louis, July 2, 1917 (Carbondale, IL, 1964), 157-73.

23. The Bystander, 2 November 1917, noted that soldiers' "families will be bettered." Typical wages in Alabama for a father of three or four, the black newspaper reported, amounted to eight dollars per week; in the army, he would get fifteen dollars per month for his wife plus ten dollars per month per child, in addition to his regular pay of fifteen dollars. The Camp Dodger, 21 December 1917 and 11 January 1918, reported that most of the money African-American soldiers made was sent home. On transportation costs north, see Marks, Farewell, 36, 47. 
ally wrote to the governor of Alabama asking him to dissuade potential emigrants, and the Alabama governor warned African Americans not to go to Camp Dodge- unless, we may assume, they were drafted. ${ }^{24}$

This fear of black migration did not sit well with many Des Moines African Americans. Iowa's weekly African-American newspaper, the Bystander, pointed out that Governor Harding had not contacted the governors of North Dakota, Minnesota, and Illinois to dissuade white camp followers from those states from moving to Des Moines. And many prominent Des Moines African Americans, led by attorney S. Joe Brown, rallied at the Bethel African Methodist Episcopal Church in opposition to the plans to obstruct the movement of the conscripts' families. Arguing that moving north would expand the rights and opportunities of African Americans, the group passed a resolution pledging to support families who chose to move to Des Moines and urging Congress to enact, "as a war measure, a federal statute making it treason .... to refuse to furnish .... any of the necessities of life, including food, clothing, and shelter, to any person in the military service of the United States, or to any member of his family because of the race, color or previous condition of such person. ${ }^{125}$

IN SPITE OF FEARS of an influx of African-American civilians, the stereotype of the loyal, cheerful, grateful Negro meant that, unlike in the South, few northerners expected disturbances from black soldiers. In fact, the Des Moines white press barely reported instances of disloyalty or assertions of rights among African Americans. After African-American barber William Holladay, entertaining a black sergeant in his home, made black nationalist antiwar statements that apparently were not persuasive to the military man, Holladay was arrested for "inciting to mutiny and insulting the president's wife." $\mathrm{He}$ was accused of claiming that "the Negro has no flag. I would

24. Des Moines Capital, 1 and 10 November and 3 December 1917; Des Moines Register, 15 November 1917.

25. Des Moines Register, 26 November 1917; Des Moines Capital, 26 November 1917; Bystander, 16, 23, and 30 November and 7 December 1917. 
rather live under the German crown than under the rule of prejudiced Americans. ... It is an outrage the way Negro conscripts are treated at Camp Dodge." But only one newspaper reported his arrest, and no follow-up stories appeared. ${ }^{26}$

Potentially more serious was the possibility that armed African Americans would begin to demand equal treatment. Trouble with recently transferred black Regular Army (career) troops in Houston, Texas, in August 1917 would set the context for War Department treatment of National Army (drafted) African Americans. Outraged at segregationist practices and police abuse, a black company used its military training to try to make democracy safe at home, marching on downtown Houston and wreaking havoc before returning to the base. Nineteen people were killed in the exchange of gunfire, all but two of them white. The army later executed nineteen African Americans, the first thirteen in December 1917 before the War Department could review their sentences. The specter of Houston-the discipline, public relations, and morale problems confronting military authorities when soldiers challenged segregation and disrespectful treatment-haunted the War Department throughout the war. ${ }^{27}$

26. Des Moines Capital, 13 February 1918. The Capital, which ran the story, had an overriding interest in ferreting out disloyalty; its editor, Lafayette Young, conveniently doubled as state chair of the Council for National Defense, and distinguished himself as extreme even within CND circles by calling for the stockading of five thousand Iowans for the duration of the war. William J. Breen, Uncle Sam at Home: Civilian Mobilization, Wartime Federalism, and the Council of National Defense, 1917-1919 (Westport, CT, 1984), 85, 226; Council Bluffs Daily Nonpareil, 5 April 1918. Holladay was accused of violating the federal Espionage Act, but was apparently never indicted. African-American opposition to the war is best described in Theodore Kornweibel Jr., "Apathy and Dissent: Black America's Negative Responses to World War I," South Atlantic Quarterly 80 (1981), 322-38. For possible influences on Holladay's politics, see Stephen R. Fox, The Guardian of Boston: William Monroe Trotter (New York, 1970); Theodore Kornweibel Jr., No Crystal Stair: Black Life and The Messenger, 1917-1928 (Westport, CT, 1975); and Judith Stein, The World of Marcus Garoey: Race and Class in Modern Society (Baton Rouge, 1986). On Ellen Wilson's commitment to racial segregation, see Florette Henri, Black Migration: Movement North, 1900-1920 (Garden City, NY, 1975).

27. Robert V. Haynes, A Night of Violence: The Houston Riot of 1917 (Baton Rouge, 1976), 223, 273, 302-4, 316, 319-20; Frederick Bernays Wiener, "American Military Law in the Light of the First Mutiny Act's Tricentennial," Military Law Review 126 (1989), 17. 
Des Moines's mainstream press sought to suppress black voices raised to draw attention to the implications of the incident for local readers. Des Moines NAACP activist Lillian Smith wrote a letter to the Des Moines Capital in which she hailed the Houston mutineers as "heroes." The Capital refused to publish the letter, but the Bystander printed it, and Capital editor Lafayette Young passed it on to the local Bureau of Investigation. ${ }^{28}$

Despite the press's efforts to ignore them, the conditions that led to the riot in Houston were not limited to southern training camps. At Camp Dodge, the spark of racial tension was much closer to the surface than anyone with a printing press wanted to admit. On April 16, 1918, a dispute between a restaurant owner in "Army City" (near the base) and a black soldier threatened to ignite the spark. The soldier picked up a brick, and the owner responded by brandishing a revolver. Soon, two hundred black soldiers were marching on the restaurant in what the Evening Tribune called a "Negro riot" and the Capital more accurately labeled a "near riot." Quick action by military police persuaded the soldiers to return to camp. Subsequently, base authorities put the restaurant off limits to soldiers and, for reasons not made clear in the local newspaper accounts, banned white women from working in Army City. Despite the serious implications of the event, the "near riot" was a one-day story that drew no commentary or followup from the local press. ${ }^{29}$

The camp newspaper, the Camp Dodger, also refused to draw attention to the grievances of African-American soldiers. The paper refused to publish a letter from a soldier denouncing a policy enacted in April 1918 by General C. C. Ballou, who commanded the companies of the all-black (except for officers) 92nd Infantry stationed at Camp Funston, Kansas. Ballou, who had been the original commander at Fort Des Moines, would eventually command the entire division (including troops from Camp Dodge) when it finally assembled

28. Bystander, 28 December 1917; A. P. Sherwood, Report, Department of Justice, Des Moines Bureau of Investigation, 16 January 1918, National Archives, Record Group 165, M1440 (10208), \#86.

29. Des Moines Evening Tribune, 17 April 1918; Des Moines Capital, 17 April 1918. 
from parts in several camps. At Camp Funston he ordered Negro troops not to seek to integrate establishments off base. After a soldier attempted to integrate a movie theater in the nearby town of Fort Riley, General Ballou condemned the effort as a distraction from the central purpose of winning the war. It is not surprising that, as the St. Paul Appeal reported, "many colored organizations" protested Ballou's order. ${ }^{30}$ As the two-page typewritten letter by "A Negro Soldier" to the Camp Dodger made clear, the policy was a direct challenge to the African-American leadership's rationale for supporting the war. The Negro's motive in fighting, the soldier asserted, is to "make America, and the world, a better place for HIM." More than eighty thousand African-American troops had been mobilized, the letter-writer claimed, "Yet while the Negro goes forth to vindicate Belgium, his own is LYNCHED here in America. While he goes forth to fight for the womanhood of France, the women of his own race are outraged here in America.... [Those of the Negro race] are not allowed to vote, is segregated, Jim Crowed, and commanded by those in authority, to remain silent." If the war is "'to make the world safe for Democracy,'" the soldier concluded, "Is that Democracy to include, just certain races and peoples, or 'Every race under the Sun.' If it is to include only a chosen few, it is as great an evil as 'The Divine Right of Kings.'"

General Ballou, in addressing African-American troops at Camp Funston, had suggested that black as well as white soldiers would be met by a parade at war's end, but this was scant solace for the anonymous letter writer.

But when the march is over, and the dreams are silent, these same war scarred victims would be denied service in a Lemon-

30. St. Paul Appeal, 27 April and 4, 11, and 18 May 1918; Scott's Official History, 97-98. The previous summer two soldiers from Fort Des Moines had been arrested at the Empress Theater when they refused to move to "a section set apart for colored people." Interestingly, the local Crocker Post of the GAR asked the city council to withdraw police protection from the theater as long as such discrimination continued. Bystander, 20 July 1917.

31. The letter never appeared in the Camp Dodger, but it did make its way into the "Negro Subversion" file of military intelligence. National Archives, Record Group 165, M1440 (10208) \#120; Record Group 165, 10425-57. 
ade stand. ... I love America, because it is the place of my birth. But if I am to go forth in the defense of a government that does not protect me, even when that government confesses I am right, God forbid....

Of course, in times like these, free speech is forbidden, [to] both soldiers and civilians, but we want to hear the conclusion of the whole matter from the government in its relation to the $\mathrm{Ne}-$ gro race. This matter has stirred almost every man in my regiment; as you see, it was read by us all. - A NEGRO SOLDIER ${ }^{32}$

Undoubtedly this letter was the most eloquent statement of African-American dissent to emerge from Camp Dodge, and it claimed nearly unanimous agreement among the regiment, but the paper's refusal to print the letter meant that white soldiers would not read the sentiments, even though the Camp Dodger frequently printed matters of controversy and was arguably more liberal on free speech issues than Des Moines's dailies. ${ }^{33}$ In fact, white soldiers were most likely unaware of the whole issue; segregated on the southern edge of camp, African Americans' interactions with white conscripts were limited and perfunctory, not designed to challenge the stereotypes.

AS THE FIRST WAVE of African-American conscripts prepared to leave for France, the hangings of three African Americans on July 5, 1918, and the forced witnessing of the event by the entire camp broke though the obfuscation that had obscured the actual state of race relations in and around Camp Dodge. Official orders, if not macabre fascination, dictated that the event could not be ignored, and those who witnessed it never forgot it. The hangings ironically provoked a sympathy and acknowledgment of the humanity of African Americans that no other event induced.

As the troops assembled and the death march began, Des Moines Tribune reporter Leslie Brooke was caught up in the unfolding power of the events.

32. Ibid.

33. Camp Dodger, 15 March, 17 May, and 11 October 1918. 
As the scaffold was approached-

"God save my soul," rent the death[-]like silence.

"Have mercy," and "Oh Lord save me."

The cries of the condemned men echoed and re-echoed.

Soon the shrieks of Negro soldiers, unwilling and terrified spectators, driven into a hysterical state, added to the sickening scene.

It was terrible. There was no commotion. Feinting [sic] and frantic Negroes were promptly carried to the rear.

One who had lost mental control ran straight for the gallows. ${ }^{34}$

With more detachment, the Capital reported that the "Negroes sang continually during their long march to the gallows. ... The chant was a weird, minor melody. At times the voices of the doomed men sank almost to a whimper, then rose to a shriek. This incantation was reminiscent of camp meeting days. ${ }^{\prime 35}$

If the African-American soldiers who had been placed in the front rows were shaken, their white comrades in arms were also visibly moved, as one of their officers, Russell B. Rathbun, recalled in 1978. "It was a very hot day with no wind. Thus the voices of the condemned men really reached the thousands of soldiers surrounding the scaffold. It was a horrible event. Most of us were not experienced soldiers, just ordinary young guys.... I was concerned that my recruits facing the scaffold might even panic.... I saw some of them weaving in ranks trying to stand at attention." For Rathbun, the scene was worse than anything he would later see in Europe. ${ }^{36}$

White conscripts shared Lt. Rathbun's revulsion and revealed other emotions as well. John Andres, from Elbing, Kansas, who had just been shipped up from Camp Funston two days before, remembered, "The second day when we was there, they hung three Negroes, killed them, hung them. And the whole camp had to witness that and they had us there toothey had us the closest one[s] to watch them kill the Negroes. Oh, I was mad!" Fellow Kansan Noah Leatherman noted that

34. Des Moines Evening Tribune, 5 July 1918. We might wonder about Brooke's definition of "commotion."

35. Des Moines Capital, 6 July 1918.

36. Des Moines Register, 5 July 1978. 
white soldiers had guns and black soldiers did not. Harold Hollaway's letter to his parents in nearby Linden, Iowa (Dallas County) took a cynical tone that was clearly directed at the military:

Well I was one of the honored ones to witness the hanging the other day. It was some honor, as there were only 40,000 that got to see it. I tell you they didn't live long after the rope was put around their neck. Several of the negroes and one white soldier fainted. I suppose you know as much about it as I do. If you read the paper. The Tribune told it exactly as I saw it. ${ }^{37}$

The arrests, courts-martial, and sentences all brought into question due process and equal justice for the AfricanAmerican defendants. Both the alleged victim, a seventeenyear-old former telephone operator at the camp (who was not identified in press accounts) and her boyfriend, private John Adolph Gustafson of Des Moines, testified that they were sitting on a hillside inside the camp on the evening of May 24 when a group of black soldiers attacked them. Gustafson was knocked out and the woman was raped. A roundup of the entire black population of the camp resulted in the arrest of five soldiers. The court-martial convened within a week of the arrests. Of the five soldiers originally accused, one was acquitted because of lack of evidence and one had his conviction reversed by the War Department. The defense apparently argued that the sex was consensual and paid for. Newspaper accounts that the three privately confessed while awaiting execution sound more self-reassuring than persuasive; Robert Johnson, at least, proclaimed his innocence on the scaffold. ${ }^{38}$

The transcript of Stanley Tramble's trial reveals an unprepared defense (perhaps inevitable given the rush to judgment)

37. John Andres, Schowalter Oral History Collection; Noah Leatherman, Diary Kept by Noah H. Leatherman while in Camp during World War I (Linden, Alberta, 1951,) 26; Hollaway to parents, 7 July 1918, "World War I Experiences of Pvt. Harold M. Hollaway," p. 90, Iowa Gold Star Museum.

38. Des Moines Register, 5 July 1978; Des Moines Capital, 6 July 1918. Frances E. Hawthorne, African Americans in Iowa: A Chronicle of Contributions, 1830-1992 (Des Moines, 1992), 39, claims that the camp newspaper stated that the victim was not raped, but I have been unable to find this. It did say, "The evidence against these men is absolutely conclusive." Camp Dodger, 31 May and 5 July 1918. 
capable only of raising questions to witnesses about how dark it was. For Tramble, who at age 32 should not have been drafted, the damning evidence was his own: his advocates allowed him to testify, and what had been questionable eyewitness identification became self-incrimination. As the court repeatedly reminded him to raise his voice to an audible level, Tramble minimized but did not deny his own participation. ${ }^{39}$

Procedural military justice was improving during the war, and-as was not the case with the majority of the Houston mutineers - the appeal to the War Department preceded the executions. ${ }^{40}$ That appeal was certainly more than perfunctory: one conviction was reversed. Moreover, Secretary of War Newton Baker, who personally opposed the death penalty, had convinced President Wilson to commute the death sentences of political conscientious objectors and of those convicted of breaches of military discipline. But Wilson did not often intervene when courts-martial brought convictions for crimes that carried civilian death penalties. ${ }^{41}$ Apparently, for Alabama African Americans, southern "justice" applied even when they were in the North.

39. Record of Trial by General Court Martial of Private Stanley Tramble, May 31, 1918, Camp Dodge, Iowa, photocopy at State Historical Society of Iowa, Iowa City (original transcript at National Archives). Twelve days after the incident the victim tested positive for syphilis, a fact that was not brought out at the trial. Such early diagnosis is rare but not unheard of; "ten to ninety days after exposure" is the medical range, and twenty-one days the average. William J. Brown, et al., Syphilis and Other Venereal Diseases (Cambridge, MA, 1970), 21. It is not clear whether the defendants were tested.

40. The appeals process in the military justice system was unclear during World War I, and a feud between the highest officials in the Judge Advocate General office over the nature of the authority of the review process lasted longer than the war. One historian of military justice has concluded that the precipitous Houston executions were "perfectly legal... under existing rules." Jonathan Lurie, Arming Military Justice (Princeton, NJ, 1992), 46-87, 69. Compare Wiener, "American Military Law," 17-18.

41. C. H. Cramer, Newton D. Baker, A Biography (Cleveland, 1961), 108-9. Baker boasted to a postwar audience that "the Army of the United States in this war is the only army that ever engaged in active military operations on an extensive scale of which it can be said that not a single soldier was executed for a purely military offense" (emphasis added). Baker, "Some Legal Phases of the War," American Bar Association Journal 7 (1921), 327. 
If the penalty was entirely consistent with southern racism, the military justification for the severity of the punishment did not address race: instead, prosecuting Judge Advocate W. A. Graham invoked the rhetoric of war propaganda to justify the sentence. "Acts of a rapine nature cannot be tolerated, ... especially among men who are being trained to combat a system of frightfulness in which are included many acts of a similar nature." ${ }^{42}$

Two characteristics stand out in white newspaper accounts of the executions: surprise at the condemned men's humanity, and the need to justify the legal process. According to the Evening Tribune, the three were "not the degenerate type of Negro one would suppose," a sentiment the chaplain apparently shared: "Chaplain Jockinson says the convicted Negroes were not the brutal type with which one usually associates crimes of the sort which they committed. He said the prisoners acted like gentlemen." ${ }^{\prime 43}$

The Evening Tribune, which provided more extensive coverage than the other local dailies, continued its uneasy approval of the hangings with an editorial that contrasted the executions with lynchings:

Nothing could be farther apart emotionally than the awed and trembling throng of soldiers which watched the legal hanging of three criminals and the maddened or cynical crowd which makes up a lynching party.

There will be no repetition at Camp Dodge of the crime committed by the men upon the gallows, and the race hatred which might have been engendered and persisted under other circumstances is likewise dissolved by the tremendous emotional effect which was produced at the camp yesterday. ${ }^{44}$

In contrast with white fascination, most local African Americans maintained a discreet silence regarding the whole affair. The Bystander did not broach the subject, even though it had devoted extensive coverage to both Fort Des Moines and, to a somewhat lesser extent, Camp Dodge. It had also provided an

42. Tramble court-martial transcript, 4.

43. Des Moines Evening Tribune, 5 July 1918; Des Moines Capital, 6 July 1918.

44. Des Moines Evening Tribune, 6 July 1918. 
outlet for those who had objected to efforts to obstruct soldiers' families from moving to Des Moines and those who decried the military's attempts to back away from its commitment to integrating communities where African Americans were trained. But perhaps reporting on the trial of three African Americans on a charge of rape would have seemed less consistent with the editor's stated mission to "observe and note the progress that different members of my race are making where they are found"; "by publishing those items of racial progress and uplift we encourage and inspire the race to better and higher ideals .... and show to the world that our race is worthy of equal treatment and full justice in this country. ${ }^{\prime 45}$

The forced witnessing of the hangings was undoubtedly intended as a deterrent to any future incidents of a similar nature. ${ }^{46}$ In fact, however, some of the witnesses expressed resentment of a military hierarchy that had overstepped the boundaries of good judgment. The incident also uncovered among the reluctant observers a hidden reservoir of sympathy for the hanged men's humanity. Whether such sympathy was lasting is much harder to gauge. And certainly not all of the effects of the public spectacle were positive. Violence at the camp, particularly violence directed against conscientious objectors who were detained at the camp, increased in the wake of the hangings. ${ }^{47}$

45. Bystander, 8 June 1917. One Des Moines African American, Isabel-Green of 1210 Center Street, did broach the delicate subject, and was summoned to the office of Bureau of Investigation agent S. M. Cox. "They got the same treatment here as in Germany," she was reported as saying. Cox thought her "a poor, ignorant negro, and we believe through kindness and fairness she understands better this country's attitude and that she is patriotic enough to obey the law." S. M. Cox, 14 August 1918 report, National Archives, Record Group 65, Case \#269745, in Federal Surveillance, reel 11, 0410.

46. The army had executed the Houston mutineers in secret. The condemned men had been transferred (twice), so the deterrent effect of a publicly witnessed execution would have been questionable. Haynes, Night of Violence, 223, 273, 302-4, 316, 319-20.

47. Camp Dodger, 16 August 1918; American Civil Liberties Union Papers, Mudd Manuscript Library, Princeton, NJ, vol. 6, 511-14, 520, 539, and vol. 80, case \#14871; Military Intelligence Report, National Archives, Record Group 165, Case \#10487 (804); George Miller, What Next? (Kalona, IA, 1974), 28. For a discussion of studies showing a clear chronological link and claiming a causal connection between executions and "brutalization" of the larger 
WHILE BOOSTERS sought to keep Camp Dodge functioning after the war, its World War I incarnation was soon disassembled and the barracks were recycled into low-income housing in Des Moines. ${ }^{48}$ The hoped-for improvement in race relations was similarly ephemeral.

Toward the end of the war, the Des Moines Capital reflected editorially on the experience of having an influx of African Americans into the community. When a restaurant in Waterloo refused service to prominent Buxton, Iowa (and later Des Moines) African-American attorney George Woodson, the Capital deplored the "snub," although it generalized that "as a rule the colored people prefer to be by themselves." The paper went on to say that some of the hundreds of African Americans who had come to Fort Des Moines to train as officers "were a little disposed to pose." On the other hand,

The people of Des Moines, by virtue of Camp Dodge, have seen many thousands of Negroes during the past year and it is only just to say that these black men have behaved themselves with very great credit. Some of them were from the cotton fields of the South, making no pretensions whatsoever. But they have not intruded their society upon white people. It is a fact that on account of the colored men who have come and gone from Camp Dodge that there is a great[er] respect in central Iowa for the Negro than at any other time....

The real test in America ought not to be a question of nativity, but one of manhood. It has been said that the Negro does not always know his place. This can be said of many thousands of white people. ${ }^{49}$

The editorial, while on the surface an endorsement of progressive race relations, reveals a profound sense of denial of what life was like for the average African American in Des Moines or stationed at Camp Dodge. Segregation in restaurants and

society, see William J. Bowers, et al., Legal Homicide: Death as Punishment in America, 1864-1982 (Boston, 1984), chaps. 8 and 9.

48. Grover, "Camp Dodge," 62; James E. Jacobsen, "Historical Residential Architecture in Des Moines, 1905-1940" (unpublished paper, 1997, photocopy in Des Moines Public Library), 52, 55.

49. Des Moines Capital, 24 August 1918. 
other public accommodations, despite official War Department disapproval, remained common. ${ }^{50}$

The Capital acknowledged no recognition of the hostility facing those who moved to Des Moines to be with loved ones at Camp Dodge, no evidence of the ambivalence AfricanAmerican soldiers felt when told they were fighting for democracy abroad while being advised to accept continued prejudice at home, not even any recollection of the hangings and the forced witnessing of the executions. "Not intruding" was much more likely to be a virtue in the eyes of whites than an effective strategy for blacks to move toward equality.

The assertion that many whites as well as blacks did not know their "places" was revealing if not reassuring. The Capital's lack of clarity about just what those places were-other than, perhaps, the "colored people's" preference for separation-was necessary to maintain the illusion for its white readers that their city did not practice racial discrimination. African Americans, of course, had no such illusions, but their voices were suppressed or isolated.

That the imposition of a brutal, racially charged, southernstyle penalty would lift the veil obscuring the more subtle northern racism suggests that attitudes of the majority society might not have been easily changed by the wartime heroism of African Americans. What changed attitudes was not so much valor in action as human interaction. Alabama African Americans may have escaped some of the most brutal forms of overt racism when they were sent to Camp Dodge, but their hopes for racial advancement as a result of their wartime sacrifices went unfulfilled. Racial restrictions were still very much in place in Iowa and elsewhere after the war. America would go

50. Cools, "The Negro in Typical Communities," 59; Chase, "Struggle for Equality," 308. Another summing up occurred when assistant intelligence officer Major Jackson R. Day responded to a military intelligence questionnaire. Day's responses were perfunctory, in marked contrast to his venting in response to a questionnaire on conscientious objectors. "Cordial but distant relations prevail between colored and white soldiers in this camp.... There is no social intermingling, however there is no apparent ill feeling." National Archives, Record Group 165, 10218-244, in Federal Surveillance, Reel 20, 0115. Day's bitterness toward objectors, which his superior considered his "pet project," can be found ibid., 10902-51 (35). 
through another war in segregated units before African Americans could engage in such a simple act as sitting down at a lunch counter in downtown Des Moines. 
Copyright of Annals of Iowa is the property of State of Iowa, by \& through the State Historical Society of Iowa and its content may not be copied or emailed to multiple sites or posted to a listserv without the copyright holder's express written permission. However, users may print, download, or email articles for individual use. 